\title{
SPATIAL DISTRIBUTION OF SOIL MOISTURE AND ITS INFLUENGE ON STAND STRUCTURE IN A LOWLAND DIPTEROCARP FOREST IN PENINSULAR MALAYSIA
}

\author{
Marryanna $L^{1, *}$, Noguchi $\mathbf{S}^{2}$, Kosugi $\mathbf{Y}^{3}$, Niiyama $\mathbf{K}^{4}$, Itoh $\mathbf{M}^{5}$, Sato $\mathbf{T}^{2}$, Takanashi $\mathbf{S}^{2}$, Siti-Aisah $\mathbf{S}^{1} \&$ \\ Abd-Rahman $\mathbf{K}^{1}$ \\ ${ }^{1}$ Forest Research Institute Malaysia, 52109 Kepong Selangor Darul Ehsan \\ ${ }^{2}$ Forestry and Forest Products Research Institute (FFPRI), Tsukuba, Ibaraki 305-8687, Japan \\ ${ }^{3}$ Graduate School of Agriculture, Kyoto University, Kyoto 606-8502, Japan \\ ${ }^{4}$ Tohoku Research Center, Forestry and Forest Products Research Institute, 92-25 Nabeyashiki, Shimo-Kuriyawa, Morioka, \\ Iwate, 020-0123, Japan \\ ${ }^{5}$ Center for Southeast Asian Studies, Kyoto University, Kyoto 606-8501, Japan
}

*marryanna@frim.gov.my

Submitted October 2017; accepted November 2018

\begin{abstract}
In tropical rainforests the pattern and quantity of rainfall influence various ecosystem functions, as well as forest stand structure by controlling soil water status. In the present study, spatial distribution of volumetric soil water content (VSWC), measured over 1 year, was compared with stand structure in a Southeast Asian tropical rainforest. Forest surface-layer VSWC was determined by the relative elevation and soil physical properties. The patterns of spatial variation in surface-layer VSWC and residual VSWC during dry period suggested that drier surface soil areas had developed forest soil texture with larger pore size. There were no relationships between VSWC and tree mortality or number of trees for all soil layer, but a significant negative relationship was found between surface-layer VSWC and basal area, and thus also biomass. This could be due to the preference of trees for drier surface areas with larger median pore size. The positive relationship between mean diameter at breast height ( $\mathrm{dbh})$ and deep layer soil water content might indicate the preference of deep layer water by big trees. On the other hand, the number of trees in Dipterocarpaceae, as well as of emergent species trees, was negatively correlated with SWC in deep soil layer.
\end{abstract}

Keywords: Soil water content, capillary pressure head, stand dynamic, dipterocarp forest

\section{INTRODUCTION}

In tropical rainforests, changes in soil moisture patterns associated with rainfall pattern have an impact on processes that affect the forest ecosystem functions, which in turn results in variations in the forest stand dynamics (Bettina et al. 2007). Temporal drought decreases soil respiration, gross primary production and increases mortality rates in tropical rainforests (Goulden et al. 2004, Kosugi et al. 2007, Kosugi et al. 2012, Meir et al. 2015).

In Amazonian rainforests, many studies have reported increased mortality related to temporal drought (Phillips et al. 2009, Lewis et al. 2011, Meir et al. 2015). Temporal drought has also been shown to induce the decrease of soil respiration in an eastern Amazonian rainforest (Goulden et al. 2004). However, while the effects of temporal variation in soil moisture on ecosystem processes are well-characterised, they differ from those of spatial variation in soil moisture. In a Southeast Asian tropical rainforest, Pasoh Forest Reserve (FR), surface soil water content had a positive relationship with temporal variation in soil respiration, but a negative relationship with spatial variation in soil respiration (Kosugi et al. 2007). Thus, there is a complex relationship between soil moisture and soil respiration. It is important to clarify how ecosystem processes are influenced by both temporal and spatial variations in soil moisture. In forest ecosystems, the spatial distribution of soil moisture may influence the forest community or stand structure. The availability of detailed data on volumetric soil water content (VSWC) is critical for classifying habitat in relation to water gradient, because plants have different 
relationships with water that are also associated with topographical variation in water availability (Marryanna et al. 2012). These are likely to be important drivers of plant population dynamics and species distribution across habitats. However, such variations in water availability have rarely been examined (Liza \& Bettina 2009).

In the present study, it was hypothesised that in Southeast Asian tropical rainforests, which do not have long dry period such as Amazonian rainforests, spatial variation of soil water content have negative relationships with the parameters of stand structure. However, it may not influence the mortality as dryness is not severe compared to Amazonian rainforests. In a Southeast Asian tropical rainforest, Pasoh, it was assumed that spatio-temporal patterns of VSWC are driven by topographical spatial patterns and soil physical properties, and that spatio-temporal VSWC patterns interact with spatial variability in biomass and stand structure such as size distribution, tree number and species distribution. To ascertain the relationship pattern between these parameters, the study underlined two major objectives: (1) to examine the spatial distribution of VSWC at different soil depths and the governing factors thereof, and (2) to determine the influence of VSWC variation on stand structure.

\section{MATERIAL AND METHODS}

\section{Site description}

The study was conducted at a 6 ha plot (Niiyama et al. 2003) in Pasoh FR (Figure 1). Pasoh FR is located at $2^{\circ} 98^{\prime} \mathrm{N}, 102^{\circ} 31^{\prime} \mathrm{E}$, at approximately 75 to 150 meters above sea level. It is a lowland dipterocarp forest with a canopy height of 30-40 m (with emergent trees $\sim 45 \mathrm{~m}$ tall). The core area (600 ha) of the reserve is primary lowland mixed dipterocarp forest, consisting of various species of Shorea and Dipterocarpus (Soepadmo 1978). The mean annual rainfall at the study site is $1800( \pm 285) \mathrm{mm}(1996-2015)$ (Marryanna et al. 2017a), peaking from March to May and from October to December (Kosugi et al. 2008). These rainy periods are characterised by their short duration and high intensity (Noguchi et al. 2003). The mean annual air temperature is $25.4{ }^{\circ} \mathrm{C}$ (1997-2011) (Noguchi et al. 2016). Typically, this area receives at least $42.6 \%$ of its annual rainfall during the northeast monsoon (November to March), 39.1\% during the southwest monsoon (April to October) and the remaining $18.4 \%$ during the transitional months (April and October) (Noguchi et al. 2003). The study area is located within a dry zone of

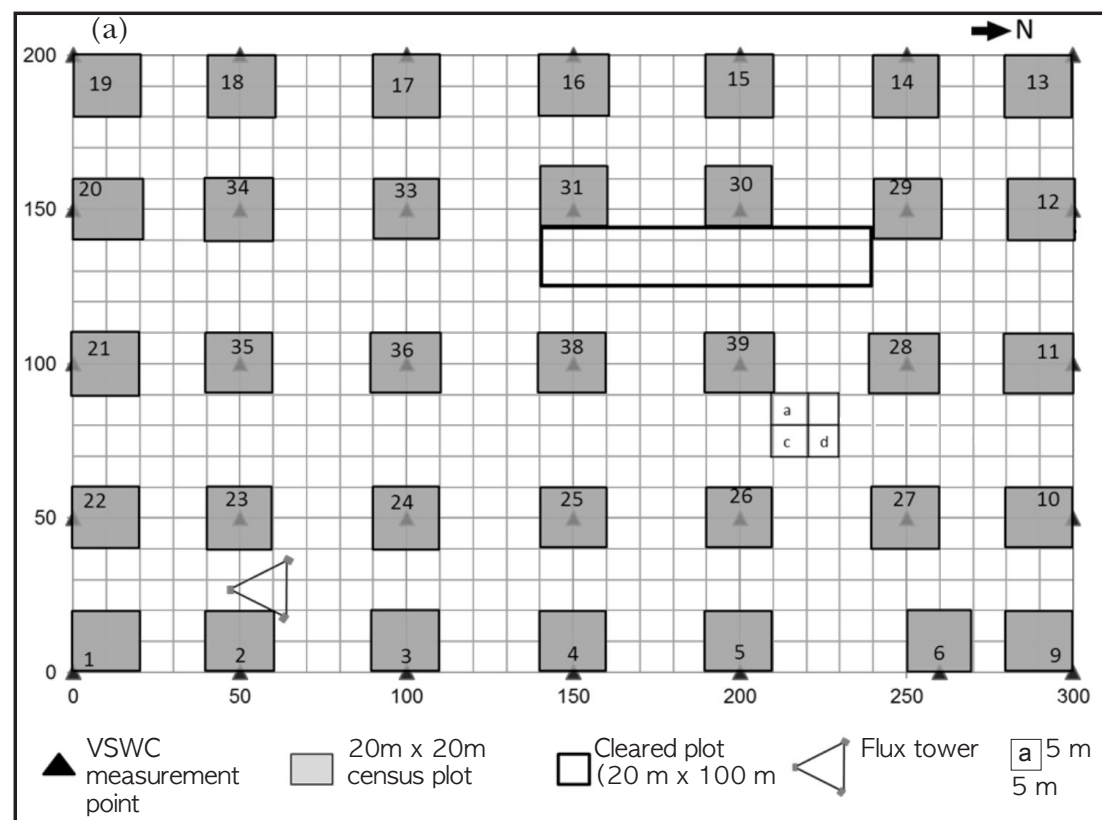

(b)

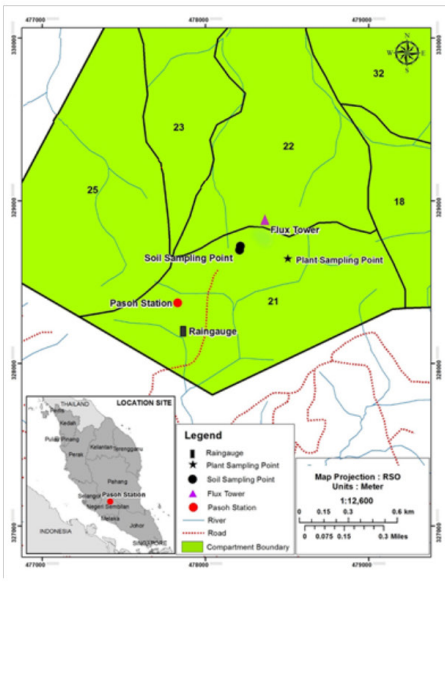

Figure 1 (a)The plot design for the measurement of VSWC and parameters of stand structure, (b) location of the 6 ha plot of Pasoh Forest Reserve in Peninsular Malaysia 
Peninsular Malaysia, and receives the lowest annual rainfall among adjacent south-eastern tropical rainforests (Noguchi et al. 2003, 2016, Marryanna et al. 2017a). Pasoh experience extreme and prolong dryness during the El Niño Southern Oscillation events (Marryanna et al. $2017 \mathrm{~b}$ ). Thus, the site is suitable for assessing the influence of VSWC on stand structure. The soil types at the study site are of petrophlinthic haplorthox and typic paleudults, both having clay topsoil with a fine granular structure and silty loam texture in deeper layers (Yamashita et al. 2003). The horizon in this area is thin $(0-2 \mathrm{~cm}$ or 0-5 cm) (Yoda 1978, Yamashita et al. 2003). Lateritic gravel is abundant below depths of $30 \mathrm{~cm}$ and increases with depth (Yoda 1978). The soil particle size distribution is characterised by low sand and high silt content (Yamashita et al. 2003). Detail soil texture of this site is listed in Table 1 . The hydraulic conductivity (Ks) of the plot area ranges from $3.3 \times 10^{-2}$ to $8.9 \times$ $10^{-4} \mathrm{~cm} \mathrm{~s}^{-1}$ (Noguchi et al. 2016). The proportion of thinner fine root to total fine root is higher than elsewhere (Yamashita et al. 2003). Fine roots are important for absorbing water and nutrients, and for dry matter production. The fine root biomass down to a depth of $2 \mathrm{~m}$ was estimated at an average of $13.3 \mathrm{mg} \mathrm{ha}^{-1}$ by the pipeline method and $16.4 \mathrm{mg} \mathrm{ha}^{-1}$ using a pit sampling method (Niiyama et al. 2003).

The topography of this forest is less steep than that of other tropical lowland forests, such as Lambir in Sarawak (Yamakura et al. 1995). Detail topography, soil morphology and pedohydrology was also reported in Adzmi et al. (2010). Generally, the vegetation type in this forest is lowland dipterocarp characterised by a high proportion of Dipterocarpaceae species. A previous study estimated that Pasoh FR houses over 800 species; 21 of which were new to science (Christine et al. 2012).

Plot $1(100 \mathrm{~m} \times 200 \mathrm{~m})$ established by Wong \& Whitmore (1970), which includes a $20 \mathrm{~m} \times 100 \mathrm{~m}$ clear-cut area under the International Biological Program (Kato et al. 1978), was expanded to a 6-ha $(200 \mathrm{~m} \times 300 \mathrm{~m})$ plot in 1994 as a long-term ecological research site (Niiyama et al. 2003). Spatial gridding was carried out using a small grid area $(5 \times 5 \mathrm{~m})$ for the tree census. A survey was also conducted to measure the elevation distribution within the plot. A $20 \mathrm{~m} \times 20 \mathrm{~m}$ $\left(400 \mathrm{~m}^{2}\right)$ grid was selected, corresponding to VSWC measurement points. In total, 35 plots were included, each $20 \mathrm{~m} \times 20 \mathrm{~m}$ (Figure 1).

Table 1 Details soil texture composition at Pasoh Forest Reserve

\begin{tabular}{|c|c|c|c|c|c|c|}
\hline Site & $\begin{array}{l}\text { Sampling depth } \\
(\mathrm{cm})\end{array}$ & $\begin{array}{l}\text { Sand } \\
(\%)\end{array}$ & $\begin{array}{l}\text { Silt } \\
(\%)\end{array}$ & $\begin{array}{l}\text { Clay } \\
(\%)\end{array}$ & $\begin{array}{l}\text { Silt \& clay } \\
\quad(\%)\end{array}$ & Silt/clay ratio \\
\hline \multicolumn{4}{|l|}{ Total pore space $(\%)$} & \multicolumn{3}{|c|}{55.30 (average) } \\
\hline \multicolumn{3}{|l|}{ Saturation point $(\%)$} & & \multicolumn{3}{|c|}{46.88 (average) } \\
\hline \multicolumn{3}{|l|}{ Field capacity $(\%)$} & & \multicolumn{3}{|c|}{34.58 (average) } \\
\hline \multicolumn{3}{|c|}{ Permanent wilting point ( $\%)$} & & \multicolumn{3}{|c|}{21.86 (average) } \\
\hline Pasoh field study & $5^{*}$ & $30^{*}$ & $45^{*}$ & $25^{*}$ & $70^{*}$ & $1.80^{*}$ \\
\hline \multirow[t]{5}{*}{ Pasoh (pit 1) } & 5.0 & 25.0 & 45.0 & 30.0 & 75.0 & 1.50 \\
\hline & 20.0 & 10.0 & 42.5 & 47.5 & 90.0 & 0.90 \\
\hline & 60.0 & 70.0 & 7.5 & 22.5 & 30.0 & 0.33 \\
\hline & 100.0 & 5.0 & 37.5 & 57.5 & 95.0 & 0.65 \\
\hline & 140.0 & 12.5 & 40.0 & 47.5 & 87.5 & 0.84 \\
\hline \multirow[t]{5}{*}{ Pasoh (pit 2) } & 5.0 & 31.5 & 47.5 & 15.0 & 62.5 & 3.17 \\
\hline & 20.0 & 27.5 & 47.5 & 25.0 & 72.5 & 1.90 \\
\hline & 50.0 & 25.0 & 45.0 & 30.0 & 75.0 & 1.50 \\
\hline & 100.0 & 47.5 & 27.5 & 25.0 & 52.5 & 1.10 \\
\hline & 140.0 & 5.0 & 37.5 & 57.5 & 95.0 & 0.65 \\
\hline
\end{tabular}

* = average of 54 samples 
Relative elevation and census data within the selected $400 \mathrm{~m}^{2}$ grid were used to assess the relationship with VSWC. Therefore, it should be noted that the data presented in this study were only for the selected grids. Clear-cut plots (Figure 1) were excluded from the analysis because it was reported that 59 of 82 original species failed to return after clear-cutting conducted from 1955 to 1959 (Niiyama et al. 2003).

\section{Volumetric soil water content}

The 50-m-interval spatial sampling grids were established in the $200 \times 300 \mathrm{~m}$ plot (6 ha plot) within Pasoh FR (Figure 1). An Amplitude Domain Reflectometry (ADR) soil moisture profile probe (PR2) were used to collect data from soil depths of $0.1,0.2,0.3,0.4,0.6$ and 1-meter. One-meter fibreglass access tubes suitable for the PR2 sensor were buried in the ground for soil moisture measurement. Soil moisture was measured 28 times, from June 28, 2016 to May 30, 2017 with 35-access tubes across the plot (Figure 1). The device had a generalised mineral and organic value, which contained two parameters $\left(\mathrm{a}_{0}\right.$ and $\left.\mathrm{a}_{1}\right)$. Default values (parameter $\mathrm{a}_{0}=1.3$ and parameter $\mathrm{a}_{1}=7.7$ ) were applied for the middle and deeper soil layer (0.4-1 m), while for the surface soil layer, soil calibration parameters specific to mineral soil was used. Twelve soil samples were taken from the forest at $0-10 \mathrm{~cm}$ soil layer at six points $(6$, $23,27,29,34,38)$, and their gravimetric values were obtained by oven drying. The samples were put into an acrylic calibration container $(\mathrm{W} \times \mathrm{D} \times \mathrm{H}: 120 \times 330 \times 95 \mathrm{~mm})$ at the field bulk density. The weight of the fresh soil and container was recorded. Water was added to the samples evenly until saturated. Samples were then dried and weights were obtained. Volumetric moisture values, obtained with the gravimetric method, and with the use of an ADR sensor were calculated. This sensor was used because the PR2 sensor was difficult to calibrate in the laboratory. The regression coefficients between VSWC $\left(\mathrm{m}^{3} \mathrm{~m}^{-3}\right)$ measured with ADR method and VSWC $\left(\mathrm{m}^{3} \mathrm{~m}^{-3}\right)$ measured with gravimetric method were determined, and obtained values of 1.44 (parameter $\mathrm{a}_{0}$ ) and 6.96 (parameter $\mathrm{a}_{1}$ ).

To obtain soil physical data at the study site, including saturated and residual soil water contents, undisturbed soil samples were collected at depths of $0-5 \mathrm{~cm}$ at 15 measurement points inside the 6 ha plot (Itoh et al. 2012). Thin-walled steel samplers with a volume of $100 \mathrm{~cm}^{3}$ (inner diameter: $5 \mathrm{~cm}$, height: $5.1 \mathrm{~cm}$ ) were used to collect soil samples. Soil water retention curves in the range of $\psi 0$ to $-1000 \mathrm{~cm}$ were measured using pressure plates and fitted using the log-normal distribution model for soil water retention (Kosugi 1996, 1997, Itoh et al. 2012). This model was used to estimate the median pore radius $\left(\mathrm{r}_{\mathrm{m}}\right)$ and pore size distribution $(\Delta)$.

\section{Precipitation}

Rainfall was measured using two 0.5-mm tipping bucket rain gauges at the top of the $52 \mathrm{~m}$ meteorological observation tower and at the station observatory from January 2016 to May 2017. The tipping bucket gauges measured rainfall at 30 minutes intervals. Rainfall was also collected daily from a storage-type rain gauge in an observatory located $430 \mathrm{~m}$ away from the flux tower (Figure 1). Data collected from tipping bucket rain gauges were compared with stored rainfall to correct possible underestimates. The antecedent precipitation index (API60) was found to have a significant relationship with VSWC, and was therefore used as a wetness index in the study area (Noguchi et al. 2016). The API60 is defined as $\sum_{i=1}^{60} P_{i} / i$, where $P_{i}=$ daily precipitation $(\mathrm{mm})$, and $\mathrm{i}=$ the number of preceding days (Kosugi et al. 2007). The API60 threshold for identifying dry and wet values was obtained from the average API60 throughout the observation periods between January 01, 2016 and May 31, 2017.

\section{Present state of stand and stand structure}

Censuses of trees in the 6 ha plot has been carried out every 2 years since 1994 (Niiyama et al. 2003). All trees with diameter at breast height $(\mathrm{dbh})>$ $5 \mathrm{~cm}$ were identified and mapped. Tree species were categorised into several ecological species groups: emergent, main canopy, understorey and others (Manokaran \& Swaine 1994, Niiyama et al. 2003). From the census data, we obtained several parameters of forest stand structure, assessed in relation to VSWC which includes dbh, basal area, mortality and number of trees. Census data from 2002 and 2012 were used to calculate the mean values between these 2 years to determine the average parameters over the 10 -year period. The basal area $\left(\mathrm{m}^{2} \mathrm{ha}^{-1}\right)$ is a sum of every tree 
within each $20 \mathrm{~m} \times 20 \mathrm{~m}$ plot, and serves as an index of biomass and occupancy. The mean dbh $(\mathrm{cm})$ is the average value of trees within each $20 \mathrm{~m} \times 20 \mathrm{~m}$ plot, representing the average tree size within the plot. Tree number $\left(\mathrm{N}^{2} 00 \mathrm{~m}^{-2}\right)$ is the count of existing trees within each $20 \times$ $20 \mathrm{~m}$ grid. The mortality (\% 10 years $^{-1}$ ) is the percentage loss of trees in each $20 \mathrm{~m} \times 20 \mathrm{~m}$ plot over 10 years, and was calculated based on the ratio the number of trees died between 2002 and 2012 to total tree number in each plot at 2002 census. The numbers of emergent, main canopy and forest floor species ( $400 \mathrm{~m}^{-2}$ ) were calculated based on species classification in census data (Manokaran \& Swaine 1994, Niiyama et al. 2003). The relationships between VSWC and the number of trees of specific families within each $20 \times 20 \mathrm{~m}$ plot was also examined. A total of 22 families that had occupancy of more than $1 \%$ in the 6 ha plot were tested (Table 2).

\section{Statistics}

Pearson correlation was used to examine the dependencies among the variables and determine $r$ and $p$ values. Three thresholds of significance were used to determine the strength of each relationship: $\mathrm{p}<0.001$, $p<0.01$ and $p<0.05$. Sigma Plot 12 was used to map the spatial distributions of VSWC, relative elevation and forest stand structure within the plot. The 2-D scatter plot was used to compel contour or relative elevation and stand dynamic distribution. The $\mathrm{x}$ and $\mathrm{y}$ axis is the grid of the 6 ha plot at $50 \mathrm{~m}$ interval.

\section{RESULTS}

\section{Physical properties of the surface soil}

The saturated VSWC $\left(\mathrm{VSWC}_{\psi}=0 \mathrm{~cm}\right)$ for 15 undisturbed surface soil samples ranged from 0.441 to 0.603 with an average value $( \pm \mathrm{SD})$ of $0.508( \pm 0.045) \mathrm{m}^{3} \mathrm{~m}^{-3}$. The residual VSWC $\left(\mathrm{VSWC}_{\psi=-1000 \mathrm{~cm}}\right)$, with approximate VSWC value at the capillary pressure head at a depth of $1 \mathrm{~m}$, ranged from 0.141 to 0.322 with an average value of $0.228( \pm 0.055) \mathrm{m}^{3} \mathrm{~m}^{-3}$ (Figure $2 \mathrm{a})$. The range between $\mathrm{VSWC}_{\psi}=0 \mathrm{~cm}$ and $\mathrm{VSWC}_{\psi=-1000 \mathrm{~cm}}$, which is an index of the effective

Table 2 Percentage of tree families' occupancy in the 6 ha plot of Pasoh Forest Reserve

\begin{tabular}{llc}
\hline No & Family name & Occupancy $(\%)$ \\
\hline 1 & Euphorbiaceae & 19.1 \\
2 & Dipterocarpaceae & 12.6 \\
3 & Burseraceae & 5.6 \\
4 & Annonaceae & 5.4 \\
5 & Sapotaceae & 3.9 \\
6 & Myristicaceae & 3.7 \\
7 & Leguminosae & 3.3 \\
8 & Ulmaceae & 3.2 \\
9 & Ebenaceae & 2.6 \\
10 & Meliaceae & 2.6 \\
11 & Flacourtiaceae & 2.6 \\
12 & Myrtaceae & 2.5 \\
13 & Anacardiaceae & 2.2 \\
14 & Guttiferaceae & 2.0 \\
15 & Lauraceae & 2.0 \\
16 & Sapindaceae & 2.0 \\
17 & Rubiaceae & 1.8 \\
18 & Polygalaceae & 1.8 \\
19 & Moraceae & 1.5 \\
20 & Fagaceae & 1.1 \\
21 & Olacaceae & 1.1 \\
22 & Alangiaceae & 1.0 \\
\hline
\end{tabular}

Percentage is based on number of each family 
VSWC range in soil, was from 0.09 to 0.431 , with an average of $0.272( \pm 0.08) \mathrm{m}^{3} \mathrm{~m}^{-3}$. The range became larger as the $\mathrm{VSWC}_{\psi=-1000 \mathrm{~cm}}$ decreased (Figure 2b). The estimated median pore size also increased as residual value decreased (Figure 2c). The correlation between $\mathrm{VSWC}_{\psi=0 \mathrm{~cm}}$ and $\mathrm{VSWC}_{\psi=-1000 \mathrm{~cm}}$ was 0.86 .

\section{Temporal variations of VSWC}

The total rainfall for 2016 was $1,495 \mathrm{~mm}_{\text {year }}{ }^{-1}$ and $1,070 \mathrm{~mm}$ for the first 5 months of 2017 (Figure 3a). Generally, conditions were dry before October 2016 and wet after November 2016, but conditions oscillated frequently depending on rainfall (Figure 3a, b). The API60 value at the 28 VSWC observation point ranged widely, from 1.89 to $132.6 \mathrm{~mm}$ (Figure $3 \mathrm{~b}$ ). The average API60 value (23.4) was used as the threshold for distinguishing between dry and wet periods. Among 28 sampling events, 12 events were grouped into dry period and 16 events into wet period. The seasonal fluctuations in VSWC corresponded to changes in rainfall pattern and API60 (Figure 3c).

\section{Spatial and vertical distributions of VSWC}

Detailed analysis revealed some inconsistencies between the distribution patterns of surface-layer VSWC and relative elevation (Figure $5 \mathrm{a}, \mathrm{c}, \mathrm{i}$ ). The wet areas near plot 6 and plot 33 (Figure 1, 5a, b, c) were hollows, where overland flow is sometimes observed during rain events. Although there were two types of soil in the 6 ha plot, VSWC did not appear to depend on the soil types. The range of spatial variation in surface-layer VSWC during the dry period (Figure $4 \mathrm{a}$ ) resembled that of the residual VSWC $\left(\right.$ VSWC $_{\psi=-1000 \mathrm{~cm}}$, Figure $2 \mathrm{a}, \mathrm{b}, \mathrm{c}$ ). Relative elevation showed a significant negative relationship with surface layer VSWC during the dry period $(\mathrm{r}=-0.61, \mathrm{p}<0.001)$ and throughout the entire period $(\mathrm{r}=-0.44, \mathrm{p}<0.01)$ (Table 3 , Figure $4 \mathrm{a})$. However, relative elevation was not significantly correlated with surface-layer VSWC during the wet period (Table 3).

\section{The relationship of VSWC with basal area and mean dbh}

Significant negative relationships were found between basal area and surface-layer VSWC (Table 4, Figure 6) for the dry $(r=-0.56$, $p<0.001)$, wet $(r=-0.37, p<0.05)$, and entire periods $(\mathrm{r}=-0.48, \mathrm{p}<0.01)$. A similarity in spatial pattern between basal area and surface-layer VSWC was apparent on the map (Figure 7a, b) but no relationships were found between basal area and VSWC at other depths (Table 4). A weak negative relationship was found between mean dbh and surface layer VSWC, but only during the dry period $(r=-0.34$, $p<0.05$ ) (Table 4, Figure 6b, Figure 7a, c) A weak positive relationship was also found between mean dbh and deep-layer $(1 \mathrm{~m})$ VSWC for the dry $(r=0.36, p<0.05)$, wet $(r=0.34$, $\mathrm{p}<0.05)$ and entire periods $(\mathrm{r}=0.35, \mathrm{p}<0.05)$ (Table 4).
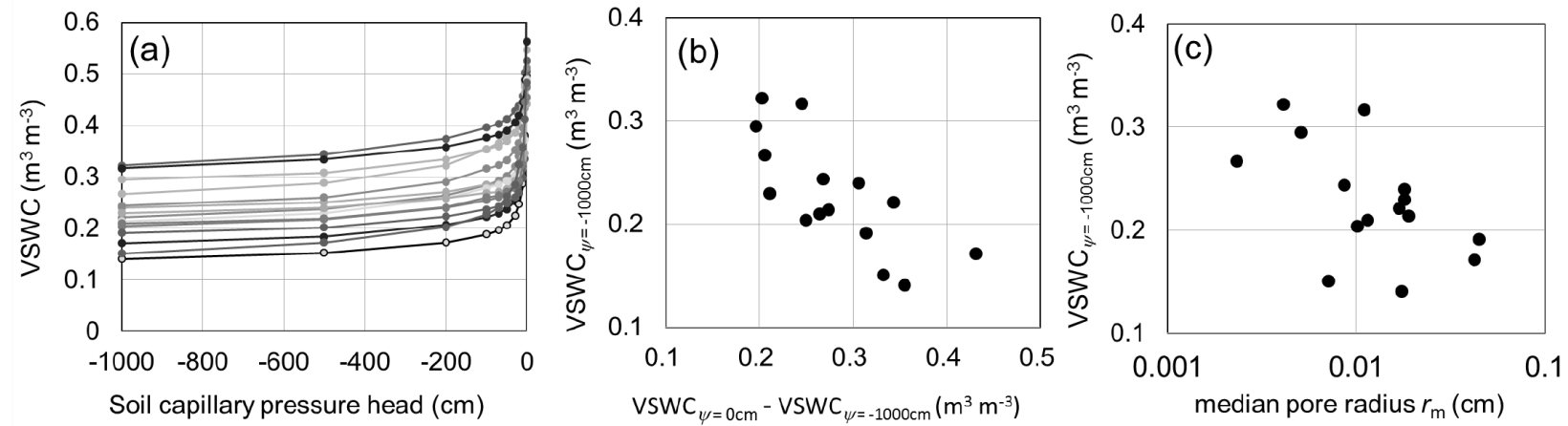

Figure 2 (a) The soil water retention curve, i.e VSWC $\left(\mathrm{m}^{3} \mathrm{~m}^{-3}\right)$ and soil capillary pressure head $(\mathrm{cm})$ at the

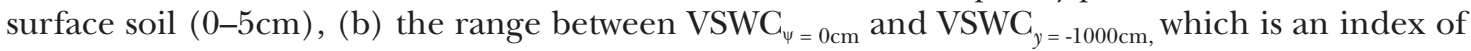
effective VSWC, and (c) the estimated median pore size using lognormal distribution model for unsaturated soil; undisturbed soil samples were collected at depths of $0-5 \mathrm{~cm}$ at 15-measurement points inside the 6 ha plot 


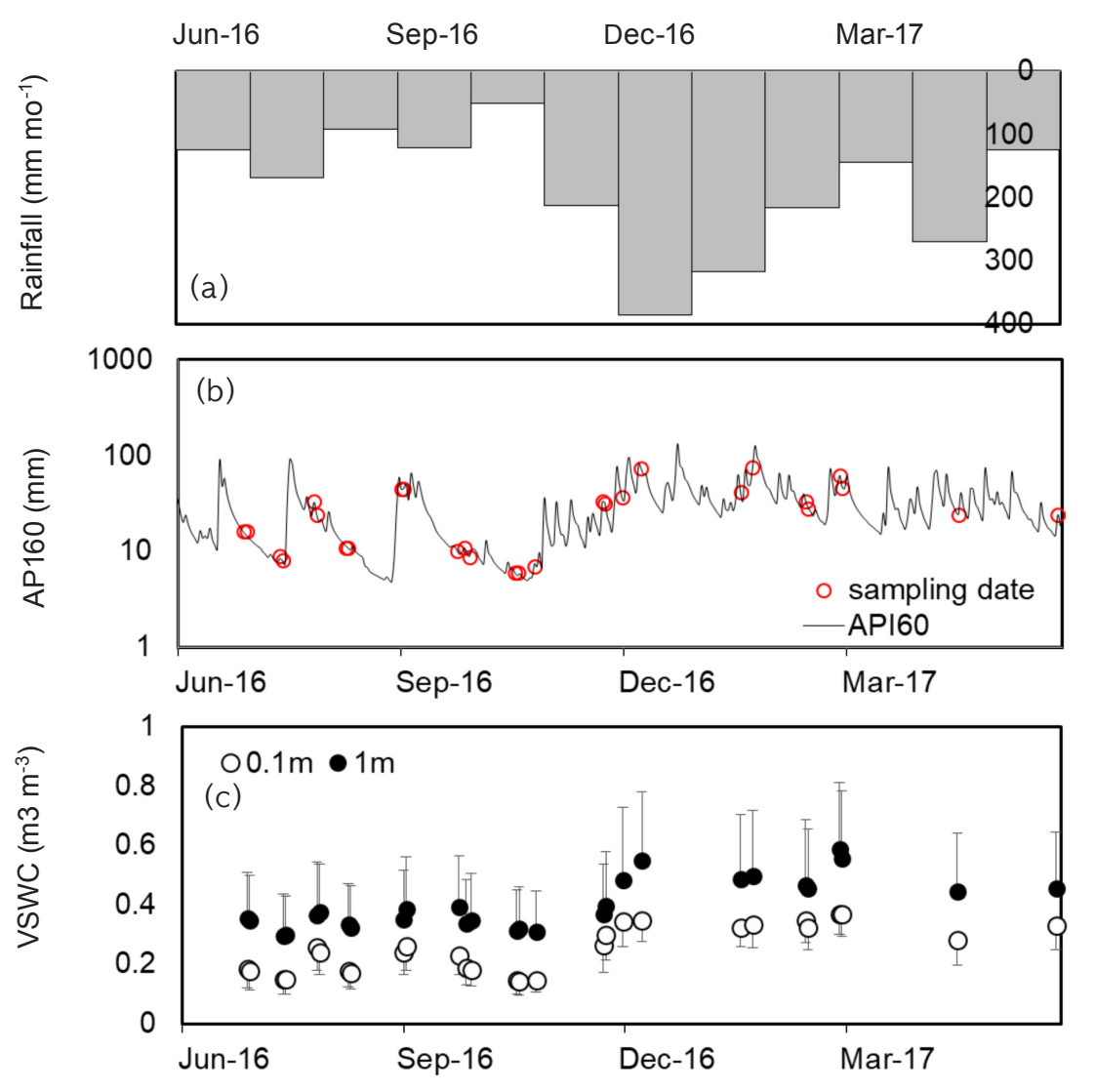

Figure 3 Temporal variations of (a) rainfall, (b) API60 and sampling date of soil moisture and (c) the average volumetric soil water content (VSWC) of $0.1 \mathrm{~m}$ and $1 \mathrm{~m}$ depth from 2016 to 2017 in Pasoh Forest Reserve; error bars shows the standard deviation
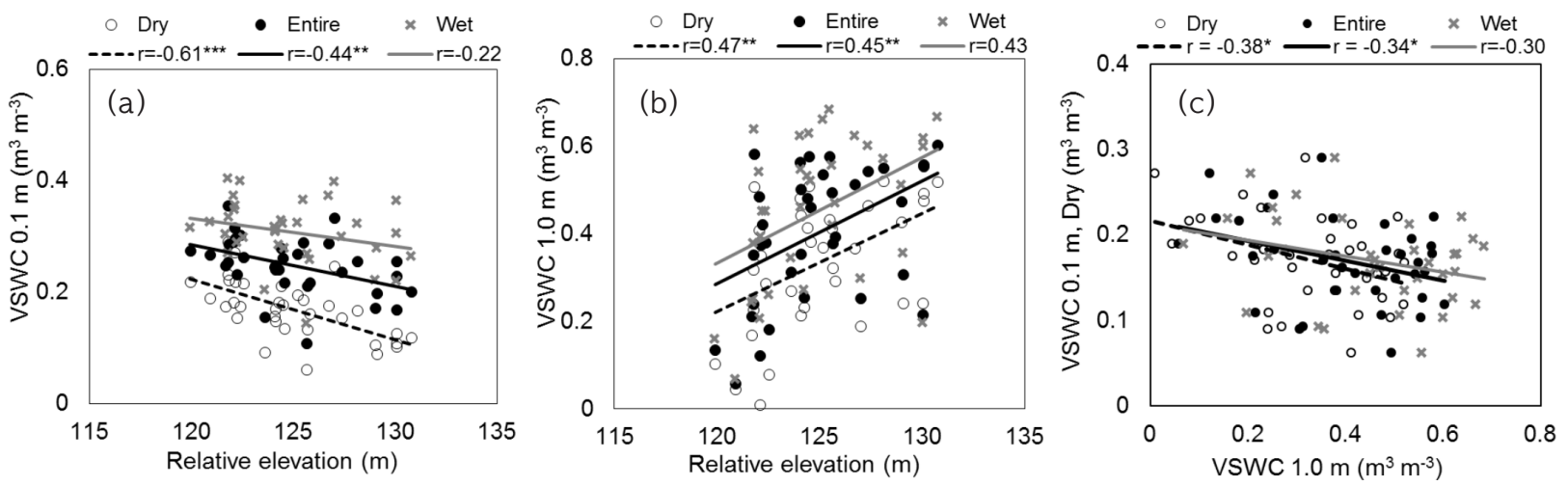

Figure 4 (a) Relative elevation and VSWC at surface layer $(0.1 \mathrm{~m})$ VSWC during dry,wet and entire periods, (b) relative elevation and VSWC at deeper layer $(1.0 \mathrm{~m})$ during dry, wet and entire periods and (c) relationship between VSWC at surface layer $(0.1 \mathrm{~m})$ and deeper layer $(1.0 \mathrm{~m}) \mathrm{VSWC}$ during dry, wet and entire periods

The relationship of VSWC with number of trees and mortality

There were no significant relationships between VSWC and either number of trees or mortality at any depth although both, number of trees and mortality, showed strong relationships with basal area, mean dbh, canopy and understorey tree species (Table 4 and 5).

\section{The relationship of VSWC with tree species}

Significant negative relationships were found between the number of emergent tree species 

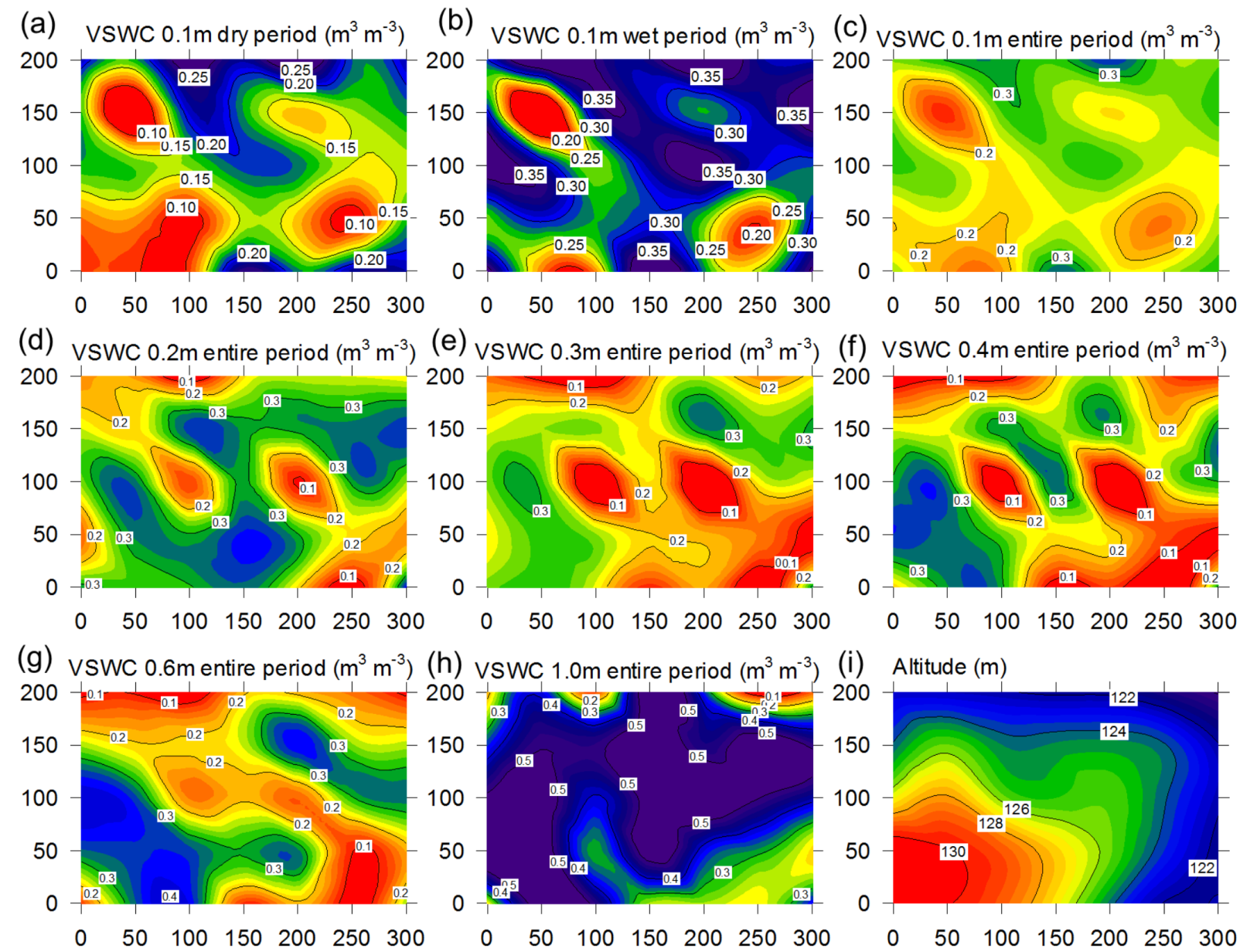

Figure 5 Spatial distribution of (a)VSWC at surface layer $(0.1 \mathrm{~m})$ during dry period, (b) VSWC at surface layer $(0.1 \mathrm{~m})$ during wet period, (c) VSWC at surface layer $(0.1 \mathrm{~m})$ during entire periods, $(\mathrm{d})$ VSWC at $0.2 \mathrm{~m}$ during entire period, (e) VSWC at $0.3 \mathrm{~m}$ during entire period, (f) VSWC $0.4 \mathrm{~m}$ during entire period, (g) VSWV at $0.6 \mathrm{~m}$ during entire period, (h) VSWC ad deeper layer (1.0 m) during entire period and (i) relative elevation in the 6 ha plot of Pasoh Forest Reserve $(n=35)$; the VSWC was measured at 6 depths $(0.1,0.2,0.3,0.4,0.6$ and $1.0 \mathrm{~m})$ during dry $($ API60 $<23, \mathrm{n}=12)$, wet $($ API60 $>23, n=16)$ and entire periods $(n=28)$; sigma plot 12 software was used to generate the spatial distribution

and deep-layer $(0.6,1.0 \mathrm{~m}) \mathrm{VSWC}$ for the dry $(r=-0.42 p<0.05, r=-0.40 p<0.05)$ wet $(\mathrm{r}=-0.45 \mathrm{p}<0.01, \mathrm{r}=-0.50 \mathrm{p}<0.01)$, and entire periods $(r=-0.45 \mathrm{p}<0.01, \mathrm{r}=-0.47 \mathrm{p}<0.01)$ (Table 4c, Figure 8a, b, Figure 9a, b). Similar but weaker negative relationships were also found between the number of understorey tree species and deep-layer VSWC for the dry $(r=-0.35$, $\mathrm{p}<0.05)$, wet $(\mathrm{r}=-0.39, \mathrm{p}<0.05)$ and entire periods $(\mathrm{r}=-0.39, \mathrm{p}<0.05)$ (Table 4, Figure 7c, 8a, d, 9a, c). However, these negative relationships was not observed in the surface and middle layers. No relationships were found between the number of canopy tree species and VSWC at any depth or period (Table 4).

No relationships were found between VSWC and 19 tree families out of the 22 most abundant families in the 6 ha plot (Table 2). Dipterocarpaceae had a significant negative relationship with VSWC at depths of 0.6 and $1 \mathrm{~m}$. For Annonaceae, a weak positive correlation with VSWC at 0.3 and $0.6 \mathrm{~m}$ and a weak negative correlation with surface-layer VSWC during the dry, wet and the entire period was found. For Ulmaceae, a weak negative correlation was found with $0.2 \mathrm{~m}$ VSWC during the dry period and the entire period (Table 4). 
Table 3 The Pearson correlation and their level of significance resulting from a regression between relative elevation and volumetric soil water content (VSWG) measured at 35 points in the 6 ha plot of Pasoh Forest Reserve

\begin{tabular}{|c|c|c|c|}
\hline \multicolumn{2}{|c|}{ Sampling period and depth $(\mathrm{m})$} & \multirow[t]{2}{*}{ Relative elevation (m) } & \multirow[t]{2}{*}{ VSWC $0.1 \mathrm{~m}$ during dry period $\left(\mathrm{m}^{3} \mathrm{~m}^{-3}\right)$} \\
\hline Dry period & & & \\
\hline & $0.1 \mathrm{~m}$ & $-0.61^{* * *}$ & \\
\hline & $0.2 \mathrm{~m}$ & 0.22 & -0.16 \\
\hline & $0.3 \mathrm{~m}$ & 0.21 & -0.30 \\
\hline & $0.4 \mathrm{~m}$ & $0.35^{*}$ & -0.29 \\
\hline & $0.6 \mathrm{~m}$ & $0.52^{* *}$ & $-0.50^{\text {** }}$ \\
\hline & $1.0 \mathrm{~m}$ & $0.47^{* *}$ & $-0.38^{*}$ \\
\hline \multicolumn{4}{|l|}{ Wet period } \\
\hline & $0.1 \mathrm{~m}$ & -0.27 & $0.69^{* * *}$ \\
\hline & $0.2 \mathrm{~m}$ & 0.33 & -0.26 \\
\hline & $0.3 \mathrm{~m}$ & $0.38^{*}$ & $-0.39^{*}$ \\
\hline & $0.4 \mathrm{~m}$ & $0.49^{* *}$ & $-0.39^{*}$ \\
\hline & $0.6 \mathrm{~m}$ & $0.54^{* * *}$ & $-0.49^{* *}$ \\
\hline & $1.0 \mathrm{~m}$ & $0.43^{*}$ & -0.30 \\
\hline \multicolumn{4}{|c|}{ Entire period } \\
\hline & $0.1 \mathrm{~m}$ & $-0.44^{* *}$ & $0.88^{* * *}$ \\
\hline & $0.2 \mathrm{~m}$ & 0.29 & -0.22 \\
\hline & $0.3 \mathrm{~m}$ & 0.32 & $-0.36^{*}$ \\
\hline & $0.4 \mathrm{~m}$ & $0.44^{* *}$ & $-0.36^{*}$ \\
\hline & $0.6 \mathrm{~m}$ & $0.54^{* * * *}$ & $-0.50^{* *}$ \\
\hline & $1.0 \mathrm{~m}$ & $0.45^{* *}$ & $-0.34^{*}$ \\
\hline
\end{tabular}

VSWC was measured at 6 depths $(0.1,0.2,0.3,0.4,0.6$ and $1.0 \mathrm{~m})$ during dry $($ API60 $<23, \mathrm{n}=12)$, wet $($ API60 $>23$, $\mathrm{n}=16)$ and entire periods $(\mathrm{n}=28)$ from 28 June 2016 to 30 May 2017; the correlation between VSWC at each depths and the surface $(0.1 \mathrm{~m})$ VSWC during dry period are also shown; ${ }^{*} \mathrm{p}<0.05,{ }^{* *} \mathrm{p}<0.01,{ }^{* * *} \mathrm{p}<0.001$, NS = not significant

\section{DISCUSSION}

\section{Physical properties of the surface soil}

Soil moisture content is often related to soil physical properties, which are described with soil water retention curve. The relationship between capillary pressure and soil water content depends on the soil pore size distribution (Kosugi 1997). Large saturated and residual VSWC values (Figure 2a) are typical for clay soil with small pore sizes, which is the type found in the 6 ha study plot in Pasoh FR.

In the surface soil layer, the decrease in residual VSWC was accompanied by an increase in effective VWC (Figure 2b), which was attributed to an increase in the median pore size of the soil (Figure 2c). Log-normal distribution model analysis for unsaturated soil hydraulic properties showed that changes in soil pore size were related to forest soil development which was changes in soil structure and texture due to root distributions and weathering processes in the forest (Kosugi 1996, 1997). It was concluded that the place with small residual VSWC had developed forest soil with large median pore size.

\section{Spatial and vertical distributions of VSWC}

The observed spatial variation of surface-layer VSWC during the dry period (Figure 4a) may have resulted from the differences in residual VSWC, and thus soil physical structure (Figure 2, 4a). The drier plots, with lower surface-layer VSWC during the dry period, might also be areas with lower residual VSWC and larger soil pore size (Figure 4c).

A clear relationship between surface-layer VSWC and relative elevation (Table 3, Figure 4a) indicates that surface-layer VSWC during the dry period was determined mainly by relative elevation. However, topographical details such as hollows or valleys near plot 6 and plot 33 may also have influenced the distribution of 


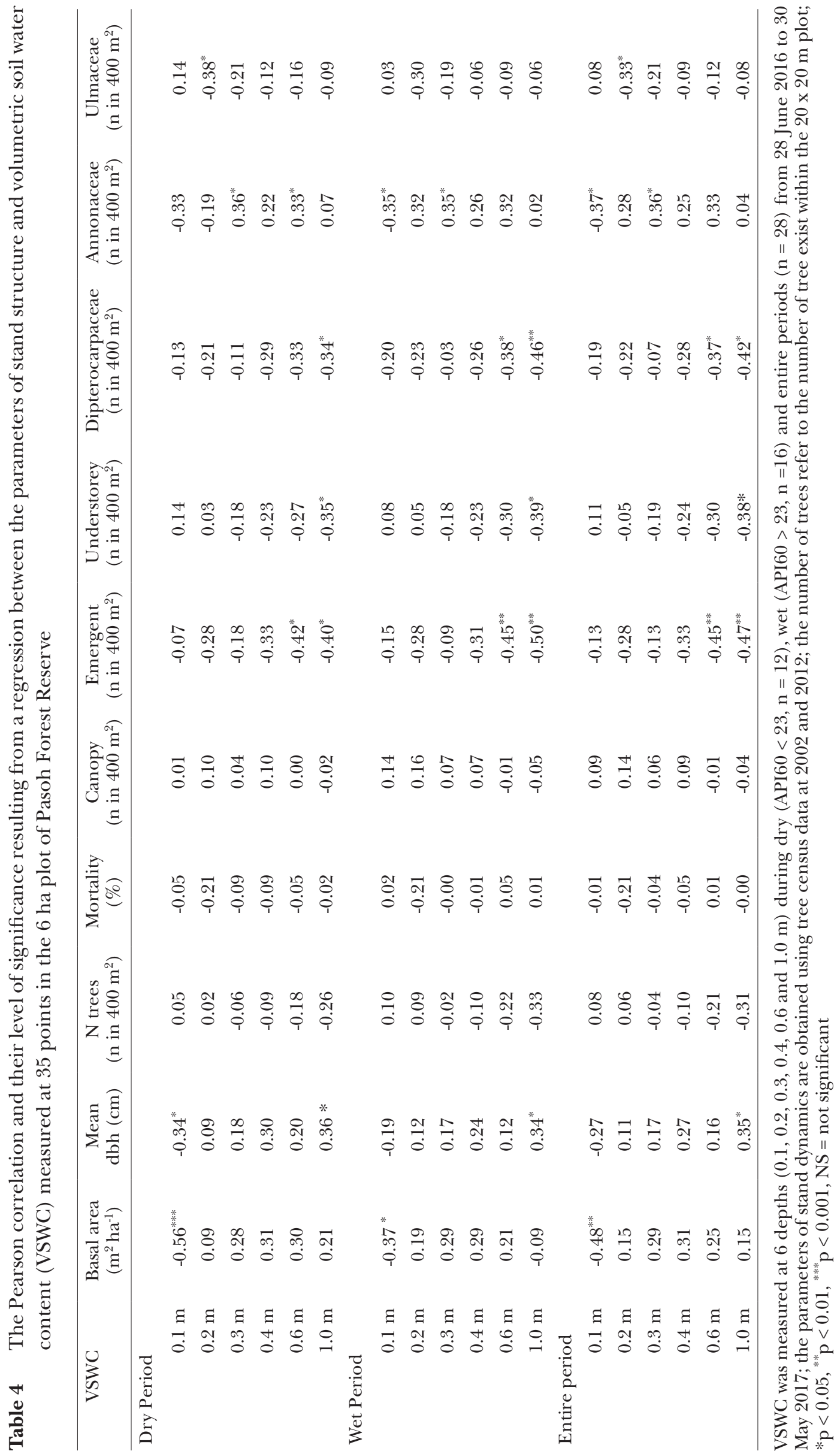



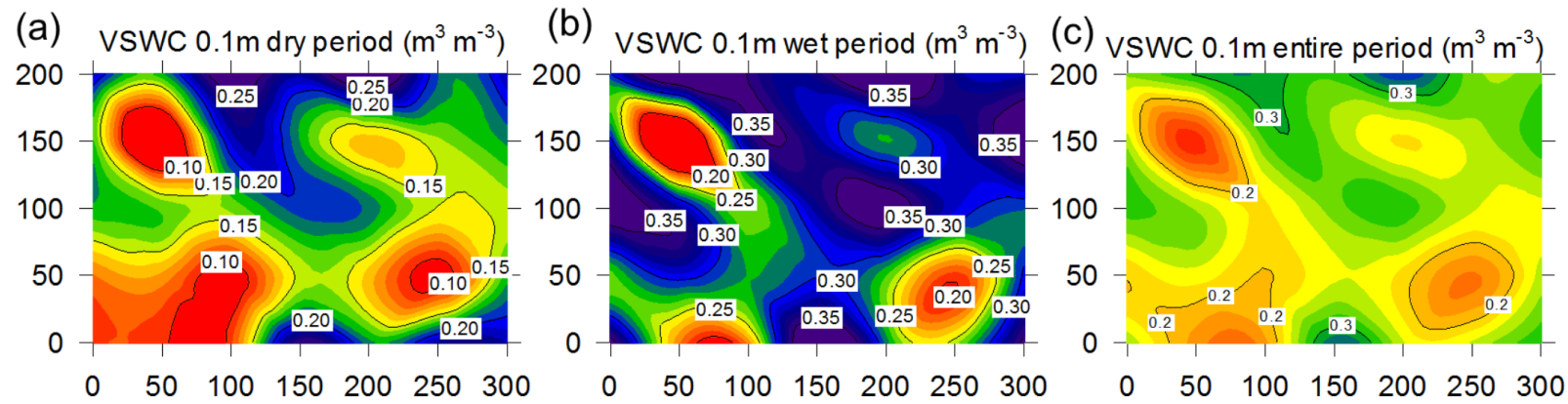

(d) Vswc $0.2 \mathrm{~m}$ entire period $\left(\mathrm{m}^{3} \mathrm{~m}^{-3}\right)$

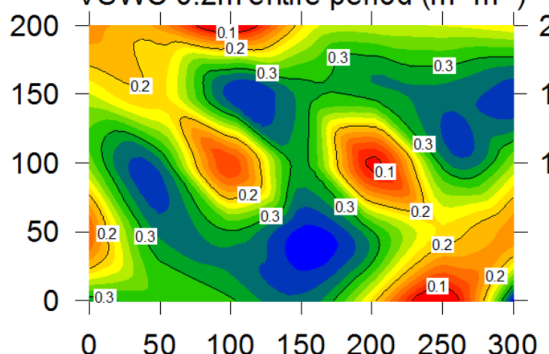

(e) VSWC $0.3 \mathrm{~m}$ entire period $\left(\mathrm{m}^{3} \mathrm{~m}^{-3}\right)$

(f) VsWC $0.4 \mathrm{~m}$ entire period $\left(\mathrm{m}^{3} \mathrm{~m}^{-3}\right)$
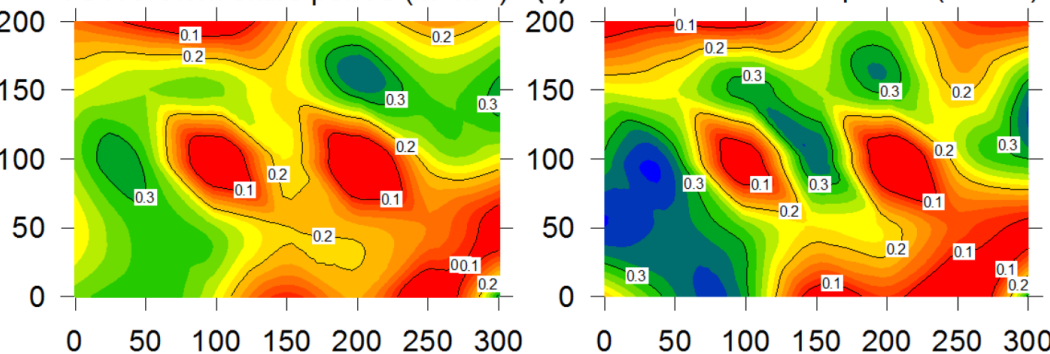

(g) vswc $0.6 \mathrm{~m}$ entire period $\left(\mathrm{m}^{3} \mathrm{~m}^{-3}\right)$

(h) Vswc $1.0 \mathrm{~m}$ entire period $\left(\mathrm{m}^{3} \mathrm{~m}^{-3}\right)$

(i) Altitude (m)
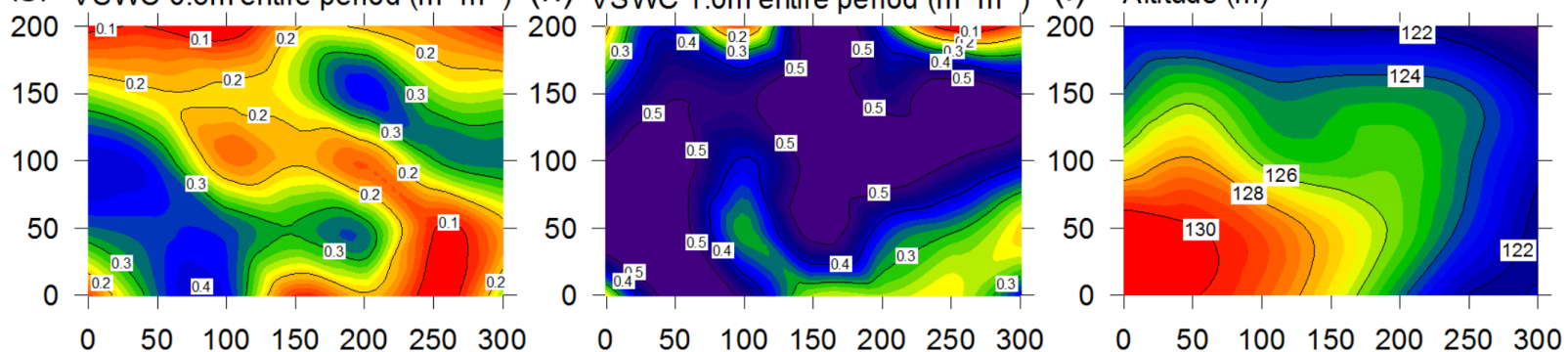

Figure 6 Relationship between (a) basal area $\left(\mathrm{m}^{2} \mathrm{ha}^{-1}\right)$ and surface layer VSWC $(0.1 \mathrm{~m})$ during dry, wet and entire periods and (b) mean dbh $(\mathrm{cm})$ and deeper layer VSWC $(1.0 \mathrm{~m})$ during dry period

Table 5 The Pearson correlation analysis of the relationship among parameters of stand structure obtained using tree census data at 2002 and 2012 in the 6 ha plot of Pasoh Forest Reserve

\begin{tabular}{lccccccc}
\hline & $\begin{array}{c}\text { Basal area } \\
\left(\mathrm{m}^{2} \mathrm{ha}^{-1}\right)\end{array}$ & $\begin{array}{c}\text { Mean dbh } \\
(\mathrm{cm})\end{array}$ & $\begin{array}{c}\mathrm{N} \text { Trees } \\
\left(400 \mathrm{~m}^{2}\right)\end{array}$ & $\begin{array}{c}\text { Mortality } \\
(\%)\end{array}$ & $\begin{array}{c}\text { Canopy } \\
\left(\mathrm{N} \text { in } 400 \mathrm{~m}^{2}\right)\end{array}$ & $\begin{array}{c}\text { Emergent } \\
\left(\mathrm{N} \text { in } 400 \mathrm{~m}^{2}\right)\end{array}$ & $\begin{array}{c}\text { Understorey } \\
\left(\mathrm{N} \text { in } 400 \mathrm{~m}^{2}\right)\end{array}$ \\
\hline Basal area $\left(\mathrm{m}^{2} \mathrm{ha}^{-1}\right)$ & - & $0.72^{* * *}$ & $0.54^{* * *}$ & $-0.48^{* *}$ & $0.43^{*}$ & $\mathrm{NS}$ & $\mathrm{NS}$ \\
Mean dbh $(\mathrm{cm})$ & $0.72^{* * *}$ & - & $\mathrm{NS}$ & $-0.55^{* * *}$ & $\mathrm{NS}$ & $\mathrm{NS}$ & $\mathrm{NS}$ \\
Number of Trees $\left(400 \mathrm{~m}^{2}\right)$ & $0.54^{* * *}$ & $\mathrm{NS}$ & - & $-0.69^{* * *}$ & $0.78^{* * *}$ & $0.36^{*}$ & $0.84^{* * *}$ \\
Mortality $(\%)$ & $-0.48^{* *}$ & $-0.55^{* * *}$ & $\mathrm{NS}$ & - & $-0.35^{*}$ & $\mathrm{NS}$ & $-0.61^{* * *}$ \\
Canopy $\left(\mathrm{N}\right.$ in $\left.400 \mathrm{~m}^{2}\right)$ & $0.43^{*}$ & $\mathrm{NS}$ & $0.78^{* * *}$ & $-0.35^{*}$ & - & $\mathrm{NS}$ & $0.49^{* * *}$ \\
Emergent $\left(\mathrm{N}\right.$ in $\left.400 \mathrm{~m}^{2}\right)$ & $\mathrm{NS}$ & $\mathrm{NS}$ & $0.36^{*}$ & $\mathrm{NS}$ & $\mathrm{NS}$ & - & $\mathrm{NS}$ \\
Understorey $\left(\mathrm{N}\right.$ in $\left.400 \mathrm{~m}^{2}\right)$ & $\mathrm{NS}$ & $\mathrm{NS}$ & $0.84^{* * *}$ & $-0.61^{* * *}$ & $0.49^{* *}$ & $\mathrm{NS}$ & - \\
\hline
\end{tabular}

$* \mathrm{p}<0.05, * * \mathrm{p}<0.01, * * * \mathrm{p}<0.001, \mathrm{NS}=$ not significant.

VSWC (Figure 5). The fact that no relationship was found between surface-layer VSWC and relative elevation during the wet period (Table 3 ), indicating that relative elevation influenced surface-layer VSWC, mainly during the dry period. As overland flow was frequently observed in the forest smaller particles in clay soil may have accumulated in hollows/valleys, creating packed clay soil with larger residual VSWC. Conversely, soil with larger pore structure and lower residual VSWC (Leigh 1978) was present in ridge areas. 
(a) VSWC $0.1 \mathrm{~m}$, dry period $\left(\mathrm{m}^{3} \mathrm{~m}^{-3}\right)$

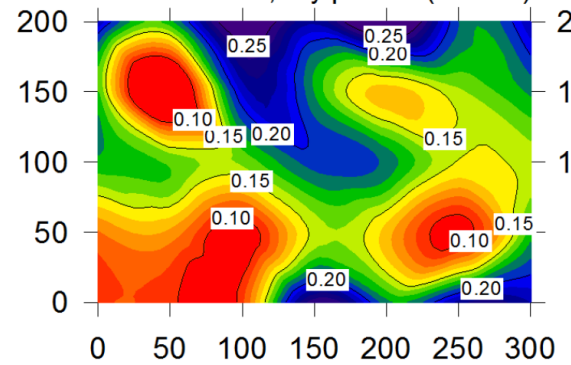

(b) Basal area $\left(\mathrm{m}^{2} \mathrm{ha}^{-1}\right)$

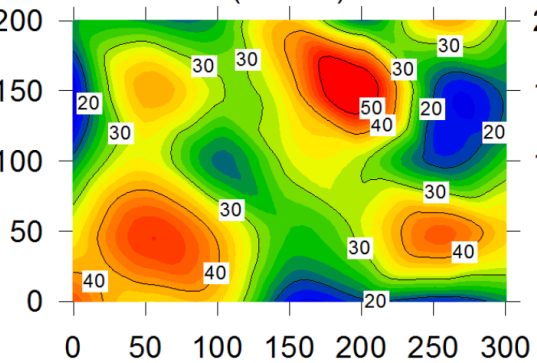

(c) Mean dbh $(\mathrm{cm})$

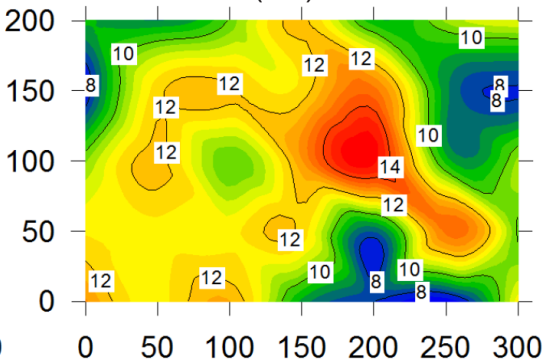

Figure 7 Spatial distribution of VSWC and stand structure parameters, (a) surface layer (0.1 m) VSWC during dry period, (b) basal area and (c) mean dbh in 6 ha plot of Pasoh Forest Reserve; stand structure parameters refer to basal area $\left(\mathrm{m}^{2} \mathrm{ha}^{-1}\right)$ and mean $\mathrm{dbh}(\mathrm{cm})$ within the $400 \mathrm{~m}^{2}$ sampling plot from 2002 to 2012
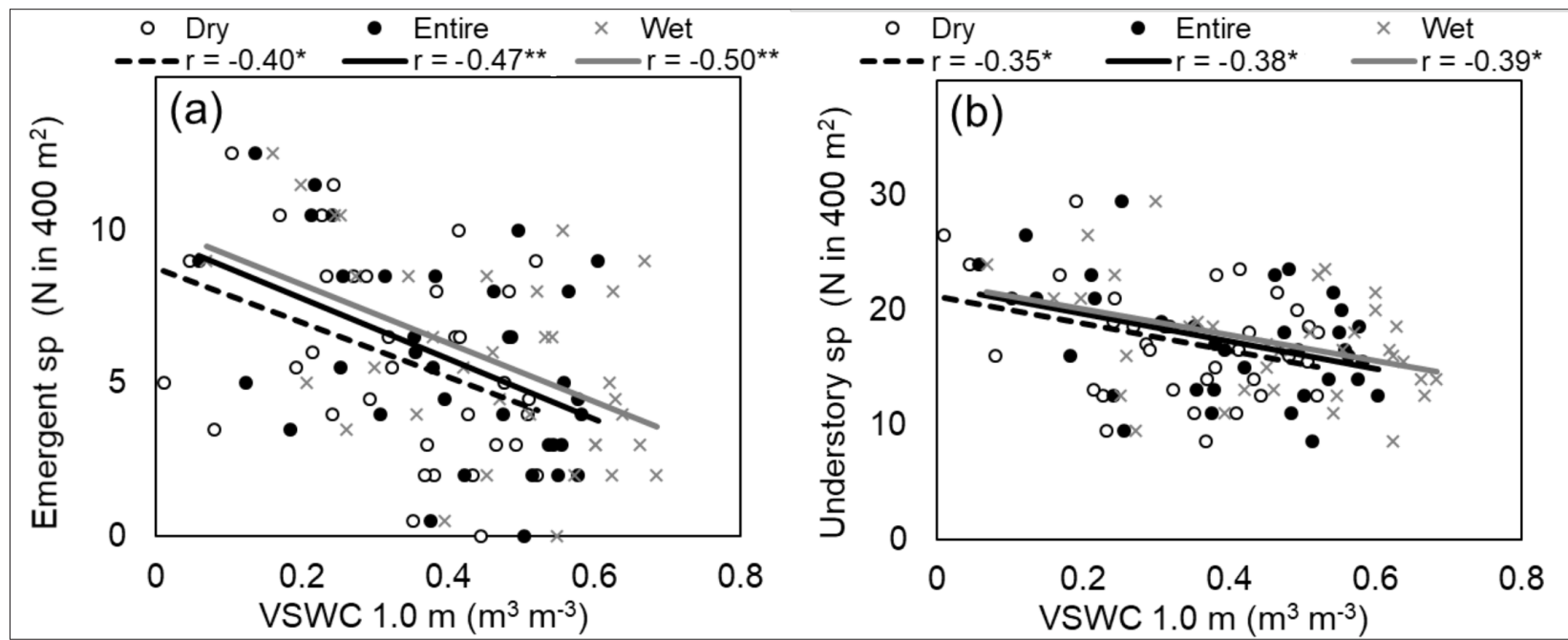

Figure 8 The relationships between VSWC at deeper layers $(1.0 \mathrm{~m})$ and stand structure parameters, (a) correlation between deeper layer VSWC $(0.1 \mathrm{~m})$ and the number of trees of emergent species during dry, wet and entire periods and (b) correlation between deeper layer VSWC $(1.0 \mathrm{~m})$ and the number of trees of understorey species during dry, wet and entire periods in the 6 ha plot of Pasoh Forest Reserve; stand structure parameters refers to number of tree of emergent and understorey species within the $400 \mathrm{~m}^{2}$ sampling plot from 2002 to 2012

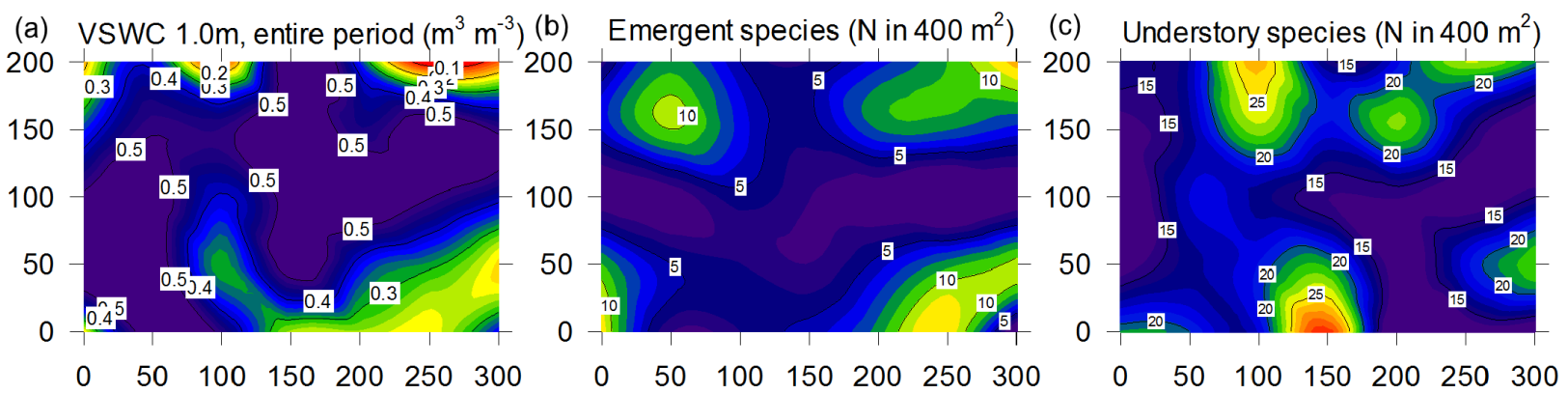

Figure 9 Spatial distribution of VSWC and stand structure parameters, (a) deeper layer VSWC (1.0 m) during entire period, (b) number of trees of emergent species and (c) number of trees of understory species; stand structure parameters refers to number of tree of emergent and understorey species within the $400 \mathrm{~m}^{2}$ sampling plot from 2002 to 2012 
The gravel layer exists between 0.2 and $0.4 \mathrm{~m}$, and sometimes deeper layer, and VSWC depends strongly on the existence of large pores caused by the gravels. In this plot, the gravel layer was less than $1 \%$ in surface layer but increased to $30 \%$ at $35 \mathrm{~cm}$ depth and to $60-80 \%$ at $60 \mathrm{~cm}$ (Yoda 1978). The occasional existence of the gravel layer caused an independent pattern in middlelayer VSWC. Although the existence of the gravel layer obscured the relationship, middle- and deep-layer VSWC tended to be higher in plots with lower surface-layer VSWC during the dry period (Table 3, Figure 4c). It can be inferred that this relationship also led to the apparent positive relationships between middle- and deeplayer VSWC with relative elevation (Figure 4b), as there was no other plausible explanation for the inverse relationship between VSWC and relative elevation.

Considering the lower surface-layer VSWC during the dry period to be the results of lower residual VSWC and larger median soil pore size, it can be concluded that this type of soil has greater water permeability. This may explain why higher middle- and deep-layer VSWC corresponded with lower surface-layer VSWC, only during the dry period. In areas that had higher surface-layer VSWC during the dry period, residual VSWC tended to be larger, and the median soil pore size smaller (Table 3). This type of soil is less permeable, and is often associated with excess overland flow. This lower level of permeability may have created drier conditions in the middle and deep soil layers.

\section{The relationship of VSWC with basal area and mean dbh}

The negative relationship between basal area and surface-layer VSWC (Figure 6a, 7a, b) shows that areas with lower surface-layer VSWC tend to have greater biomass, as basal area is a direct index of biomass. Forest biomass generally increases with stand age, and plateaus at maturity owing to balance between a decline in net primary productivity. In primary forests, such as the study site, fluctuations in biomass are largely due to the death of large trees and decay rates of woody organs (Hoshizaki et al. 2004, Yoneda et al. 2016). However, no relationship was found between surface VSWC and other stand structure parameters (such as tree mortality or number of trees), in spite of clear correlations between basal area and these parameters (mean dbh, number of trees, mortality and number of canopy tree species). This strongly suggests that basal area and surface-layer VSWC were associated in the study site. Areas with lower surface VSWC are considered to have larger median pore size, and thus less compact soil texture. This might be beneficial for trees.

A negative relationship between surface VSWC and $\mathrm{N}$ content was also observed at the study site (Kosugi et al. 2007). In dry surface soil, plant roots may be more prolific because of wide nutrient coverage, loose structure and sufficient air. These may be the reasons for the negative correlation between basal area and surface VSWC seen in this forest. It is also possible that this negative relationship caused the observed spatially negative relationship between soil respiration and surface-layer VSWC (Kosugi et al. 2007). In addition, there may be feedback effects of basal area on surface-layer VSWC. Larger root biomass increases soil cultivation, which eventually loosens clay soil texture and helps to increase soil pore size. The existence of more roots would also stimulate the absorption of water from the soil. Similar result has been reported in Lambir Hills, Sarawak, where forests over humult soils in the upper part of the 52-ha plot had more trees and greater basal area than the forests on udult soils lower in the plot (Bailie et al. 2006). This could be resulted from the difference in soil nutrients concentration and also be related to differences in other soil properties, such as water availability differences between udult and humult soils (Lee et al. 2002, Bailie et al. 2006).

The weak relationship between mean $\mathrm{dbh}$ and surface-layer $(0.1 \mathrm{~m})$ VSWC during the dry period (Table 4, Figure 6b, 7a, c) may have resulted from the strong positive relationship between mean $\mathrm{dbh}$ and basal area, as there was spatial similarity between both parameters (Figure 7b, c). Mean dbh also had a weak positive relationship with deep-layer $(1.0 \mathrm{~m})$ VSWC. This relationship might indicate the preference of deep layer water by big trees with deep rooting system. This may be also associated with the negative relationship between surface-layer VSWC and deep-layer VSWC during the dry period. Mean dbh was not related to the number of canopy, emergent or understorey species (Table 5). Therefore, the relationship between VSWC and an average tree size was unlikely to have resulted from any species group preference. 
The relationship of VSWC with tree numbers and mortality

Spatial distribution of tree numbers and mortality were not dependent on VSWC in this forest (Table 3). Many studies have considered tree mortality to be associated with temporal drought or lower level of soil water (Allen et al. 2010, Meir et al. 2015). In the Amazonian tropical rainforest (Tapajos), there was a significant increase in mortality as relative plant-extractable water decrease below to 0.5 (Meir et al. 2015). The discrepancy between our findings and those of previous studies may be due to different modes of assessment; previous studies focused on temporal effects of VSWC on mortality, while the present study focused on the spatial dependence of tree mortality on VSWC. Spatially, several studies conducted in the Amazonian forest found weak negative relationships between tree mortality and topography, although not between tree mortality and VSWC (Madelaine et al. 2007, Ferry et al. 2010). It has been shown that mortality is high in low-lying areas owing to shallow water tables, which provide low adherence and prevent roots from penetrating deep into soil (Madelaine et al. 2007, Ferry et al. 2010). Conversely, the results did not support the possibility that saturated soil conditions increased tree mortality. The intensity of the dry period may also have differed between the study site and the sites in Amazon. Amazonian rainforests have a distinct and longer dry period compared with Southeast Asian tropical rainforests, although dry and wet periods do exist in the study site as part of seasonal fluctuations with considerable variability between years (Kosugi et al. 2008).

\section{The relationship of VSWC with tree species}

The number of trees in emergent species demonstrated a negative relationship with deeplayer VSWC during all periods (Table 4, Figure $8 \mathrm{a}, \mathrm{b})$. Similarly, the number of Dipterocarpaceae trees had a negative relationship with deep-layer VSWC (Table 4). In this forest, emergent tree species were mainly within the Dipterocarpaceae family (Soepadmo 1978). Meanwhile, there was a positive relationship between mean dbh and deep layer VSWC as described before. These two phenomena contradicted each other. Although a strong relationship is possible between the number of trees in emergent species and deep layer soil water content, another possibility is that small emergent or Dipterocarpaceae species trees dislike saturated condition at deep layer. The larger tree numbers of emergent tree species is contributed by small trees, as there were no significant relationship between basal area and number of trees in emergent species (Table 5). The VSWC of 0.5 to $0.6 \mathrm{~m}$ is very close to saturated soil water content of the soil in this site. Near-saturated conditions in deep soil layers reduce the availability of oxygen, leading to reduction and anaerobic conditions that decrease soil nutrients. Oxygen supplies to the roots are critical for nutrient uptake and ion transport. It may also alter cation and anion concentration in xylem sap as well as decreased hydraulic conductance of roots (Pezeshki \& DeLaune 2012).

Understorey species also had a negative relationship with wet conditions in deep soil layers, although the effect was weaker than for emergent species (Table 4, Figure 8b, 9a, c). Since there was no relationship between the number of trees in emergent species and understorey species trees (Table 5), these are likely to have been independent trends.

Some flowering plant families, such as Ulmaceae and Annonaceae, do not prefer wet surface soil conditions. In an adjacent 50 ha plot in Pasoh FR, Annonaceae and Ulmaceae were found to be abundant on ridges or slopes and in dry alluvial soil (Marryanna et al. 2012).

It should be noted that the effects of deeplayer VSWC on emergent and understorey species trees were independent of the negative relationships between surface-layer VSWC and basal area or mean dbh; areas with lower surface-layer VSWC tended to have higher deep-layer VSWC. There were no relationship between basal area and the number of tree in emergent or understorey species found (Table 4). Therefore, it was concluded that forest biomass was greater in areas with drier surface soils having looser structures, and that some emergent and understorey species trees prefer drier, well-aerated deep-soil layers; these two trends were independent.

\section{CONGLUSION}

Understanding how the distribution of VSWC affects stand structure in tropical rainforests is particularly important, suggesting that VSWC 
controls ecosystem processes and is in turn likely to be affected by climate change. To gain insight into these phenomena, the relationships between VSWC and stand structure in Pasoh FR were analysed, located in a dry zone of Peninsular Malaysia and with lowest annual rainfall among adjacent south-eastern tropical forests.

In this forest, surface-layer VSWC was determined largely by relative elevation, although the data suggested that areas of drier surface soil had large pore size. The variability in VSWC did not affect tree numbers or mortality. However, there was a significant negative relationship between surface-layer VSWC and basal area (i.e. biomass), which may be explained by the preference of many trees to develop the roots in drier surface conditions and coarser soil textures. An independent trend for deep-layer VSWC was found, which was negatively correlated with the number of Dipterocarpaceae or emergent species trees.

The findings of the present study were interesting given that this forest has relatively low precipitation and high usage of available water (Kosugi et al. 2008, Marryanna et al. 2017). The depth of soil and existence of a large soil water reservoir may explain the complex relationship between tree species and soil conditions.

\section{ACKNOWLEDGEMENT}

The authors would like to acknowledge the contribution of RONPAKU Fellowship grant, Japanese Society for the Promotion of Sciences (JSPS). The study was supported by JSPS KAKENHI grant number 24255014, 17H01477, $18 \mathrm{H} 02239$ and by the Coca-Cola Foundation. Appreciation is extended to Forestry Department Peninsular Malaysia (FDPM) and Forest Research Institute Malaysia (FRIM) for allowing the study to be conducted at Pasoh FR. The authors also appreciate the contributions of anonymous reviewers.

\section{REFERENCES}

Adzmi Y, Suhaimi WC, Amir Husni MS, Mohd Ghazali H, Amir SK \& BAILlie I. 2010. Heterogeneity of soil morphology and hydrology on the 50 ha longterm ecological research plot at Pasoh, Peninsular Malaysia. Journal of Tropical Forest Science 22: 21-35

Allen CD, Macalady AK \& Chenchouni H. 2010. A global overview of drought and heat-induced tree mortality reveals emerging climate change risks for forests. Forest Ecology Management 259: 660-684.
Baillie IC, Ashton PS, Chin SP, Davies SJ, Palmiotto PA, Russo SE \& TAN S. 2006. Spatial associations of humus, nutrients and soils in mixed dipterocarp forest at Lambir, Sarawak, Malaysian Borneo. Journal of Tropical Ecology 22: 543-553.

Bettina MJE, Liza SC, Richard C, Thomas AK, Melvin TT, Benjamin LT \& Stephen PH. 2007. Drought sensitivity shapes species distribution patterns in tropical forests. Nature 447: 80-83.

Christine F, Marc A, Shamsudin I, Samsudin M \& Abdul Rahman K. 2012. Beyond the Red Meranti: Fresh Perspectives on Malaysia's Pasoh Forest Reserve and Climate Change. Forest Research Institute Malaysia, Kepong.

Ferry B, Morneau F, Bontemps JD, Blanc L \& Freycon V. 2010. Higher treefall rates on slopes and waterlogged soils result in lower stand biomass and productivity in a tropical rain forest. Journal of Ecology 98: 106-116.

Goulden ML, Miller SD, Da Rocha HRM, Menton C, De Freitas HC, Silva Figueira AME \& De Sousa CAD. 2004. Diel and seasonal patterns of tropical forest $\mathrm{CO}^{2}$ exchange. Ecology Application 14: S42-S54.

Hoshizaki K, Niryama K, Kimura K, Yamashita T, Bekku Y, Okuda T, QuAH ES \& Nur Supardi MN. 2004. Temporal and spatial variation of forest biomass in relation to stand dynamics in a mature, lowland tropical rainforest, Malaysia. Ecological Research 19: 357-363.

Itoh M, Kosugi Y, Takanashi S, Kanemitsu S, Osaka K, Hayashi Y, TANi M \& Abdul Rahim N. 2012. Effects of soil water status on the spatial variation of carbon dioxide, methane and nitrous oxide fluxes in tropical rainforest soils in Peninsular Malaysia. Journal of Tropical Ecology 28: 557-570.

Kato R, TADAKI Y \& Ogawa H. 1978. Plant biomass and growth increment studies in Pasoh forest. Malayan Nature Journal 30: 211-224.

Kosugi K. 1996. Lognormal distribution model for unsaturated soil hydraulic properties. Water Resources Research 32: 2697-2703.

Kosugi K. 1997. A new model to analyze water retention characteristics of forest soils based on soil pore radius distribution. Journal of Forestry Research 2: 1-8.

Kosugi Y, Takanashi S, Tani M, Ohkubo S, Matsuo N, Itoh M, Noguchi S \& Abdul Rahim N. 2012. Effect of interannual climate variability on evapotranspiration and canopy $\mathrm{CO}_{2}$ exchange of a tropical rainforest in Peninsular Malaysia. Journal of Forestry Research 17: 227-240.

Kosugi Y, Takanashi S, Tani M, Ohkubo S, Matsuo N, Mitani T, Tsutsumi D \& Nik AR. 2008. $\mathrm{CO}_{2}$ exchange of a tropical rainforest in Peninsular Malaysia. Agricultural and Forest Meteorology 148: 439-452.

Kosugi Y, Mitani T, Itoh M, Noguchi S, Tani M, Matsuo N, Takanashi S, Ohkubo S \& Nik AR. 2007. Spatial and temporal variation in soil respiration in a Southeast Asian tropical rainforest. Agricultural and Forest Meteorology 147: 35-47.

Lee HS, Davies SJ, Lafrankie JV, Tan S, Yamakura T, Itoh A, Oнкиво T \& Ashton PS. 2002. Floristic and structural diversity of mixed dipterocarp forest in Lambir Hills National Park, Sarawak, Malaysia. Journal of Tropical Forest Science 14: 379-400. 
LeIgh CH. 1978. Slope hydrology and denudation in the Pasoh Forest Reserve. Surface wash; Experimental techniques and some preliminary results. Malayan Nature Journal 30: 179-197.

Lewis SL, Brando PM, Phillips OL, Heijden GMFVD \& Nepstad D. 2011. The 2010 Amazon drought. Science 331: 554-554

Liza SC \& BetTina MJE. 2009. Seasonal and spatial variation in water availability drive habitat associations in a tropical forest. Ecology 90: 2755-2765.

Madelaine C, Pélissier R, Vincent G, Molino JF, Sabatier D, Prévost MF \& Namur C. 2007. Mortality and recruitment in a lowland tropical rain forest of French Guiana: effects of soil type and species guild. Journal of Tropical Ecology 23: 277-287.

Manokaran N \& Swaine MD. 1994. Population Dynamics of Trees in Dipterocarp Forests of Peninsular Malaysia. Forest Research Institute Malaysia, Kepong.

Marryanna L, Kosugi Y, Itoh M, Noguchi S, Takanashi S, Katsuyama M, TANi M \& Sitr Aisah S. 2017a. Temporal variation in stable isotopes in precipitation related with rainfall pattern in a tropical rainforest in peninsular Malaysia. Journal of Tropical Forest Science 29: 349-362.

Marryanna L, Kosugi Y, Takanashi S, Noguchi S, Itoh M, Katsuyama M, Matsuo N \& Siti-Aisah S. 2017b. Evapotranspiration and water source of a tropical rainforest in peninsular Malaysia. Hydrological Processes 31: 4338-4353.

Marryanna L, Rahman AK, Siti Aisah S \& Mohd MS. 2012. Association between soil moisture gradient and tree distribution in lowland Dipterocarp forest at Pasoh, Malaysia. Malaysian Journal of Soil Science 16: 23-42.

Mier P, Wood TE, Galbratth DR, Brando PM, Da Costa ACL, Rowland L \& FerReIRA LV. 2015. Threshold responses to soil moisture deficit by trees and soil in tropical rainforests: insights from field experiments. Bioscience 65: 882-892.

Nimyama K, Abd Rahman K, Iida S, Kimura K, Azizi R \& ApPANAH S. 2003. Regeneration of a clear-cut plot in a lowland dipterocarp forest in Pasoh Forest Reserve, Peninsular Malaysia. Pp 559-568 in Okuda
T et al. (eds) Pasoh: Ecology of a Lowland Rain Forest in Southeast Asia. Springer, Tokyo.

Noguchi S, Kosugi Y, Takanashi S, Tani M, Nityama K, Siti AisAH S \& MARRYANNA L. 2016. Long term variation in soil moisture in the Pasoh Forest Reserve, a lowland tropical rain forest in Malaysia. Journal of Tropical Forest Science 28: 324-333.

NogUchi S, NIK AR \& TANI M. 2003. Rainfall characteristics of Tropical rainforest at Pasoh Forest Reserve, Negeri Sembilan, Peninsular Malaysia. Pp 51-58 in Okuda T et al. (eds) Pasoh: Ecology of a Lowland Rainforest in Southeast Asia. Springer, Tokyo.

Pezeshin SR \& Delaune RD. 2012. Soil oxidation-reduction in wetlands and its impact on plant functioning. Biology 1: 196-221.

Phillips OL, Aragao LeOC, Lewis LS et al. 2009. Drought sensitivity of the Amazon rainforest. Science 323: 1344-1347.

Soepadmo E. 1978. Introduction to the Malaysian I.B.P. Synthesis meetings. Malays Nature Journal 30: 119-124.

Wong YK \& Whitmore TC. 1970. On the influence of soil properties on species distribution inn a Malayan lowland dipterocarp rainforest. Malayan Forester 33: $42-54$.

YAMAKURA T, KANZAKI M, ITOH A ET AL. 1995. Topography of a large-scale research plot established within a tropical rain forest at Lambir, Sarawak. Tropics 5: 41-56.

Yamashita T, Kasuya N, Wan Rasidah K, Suhaimi WC, Quah ES \& Okuda T. 2003. Soil and belowground characteristics of Pasoh Forest Reserve. Pp 89-109 in Okuda T et al. (eds) Pasoh: Ecology of a Lowland Rain Forest in Southeast Asia. Springer, Tokyo.

YoDA K. 1978. Organic carbon, nitrogen and mineral nutrient stock in the soils of Pasoh Forest. Malayan Nature Journal 30: 229-251.

Yoneda T, Mizunaga H, Uchimura-Tashiro Y et al. 2016. Inter-annual variations of net ecosystem productivity of a primeval tropical forest basing on a biometric method with a long-term data Pasoh, Peninsular Malaysia. Tropics 25: 1-12. 